was impressed with previous works produced by James Legge. He drew inspiration from Legge's translations. He also refers to his French Jesuit colleague Séraphin Couvreur and Angelo Zottoli. By the end of his lengthy career, Guerra had completed ten volumes of Portuguese renderings of classical Chinese texts. [4, s. 26]

Guerra presented his translation of The Book of Changes in 1984. This was one of his last translations of the whole Confucian Canon.

Both Legge and Guerra used multilingual formats.

In the article on Joaquim Guerra's Portuguese renderings of the $\mathrm{Ru}$ canonical texts, Pfister [4, 41] included a comparative chart, because it manifests how Legge's English renderings set standards of translation and a breadth of scholarly engagement with those texts that has rarely been matched in other cultural contexts.

\title{
References:
}

1. Pfister L. F. The Legacy of James Legge. International Bulletin of Missionary Research, April 1998, pp. 77-82.

2. Bowman, Marilyn Laura. James Legge and the Confucian Classics: Brilliant Scot in the turmoil of colonial Hong Kong. FriesenPress, 2016. P. 198.

3. Legge, James (1882). The Yî King. In Sacred Books of the East, vol. XVI. 2nd edition (1899), Oxford: Clarendon Press; reprinted numerous times. Preface, Pp. 14-16.

4. Pfister L. F. Joaquim Angélico de Jesus Guerra: A Brief Biography and Overview of His Portuguese Chinese Classics. Berliner China-Hefte/Chinese History and Society 46 (2015), Pp. 25-41.

DOI https://doi.org/10.30525/978-9934-26-073-5-2-6

\section{ПОЕТИКА СТАНУ МЕДІАЛЬНОСТІ ЛІРИЧНОЇ ГЕРОЇНІ У ТВОРАХ Е. ДІКІНСОН}

\author{
Скрипник Т. М. \\ кандидат педагогічних наук, \\ доиент кафедри англійської філології й перекладу \\ Національного авіачійного університету \\ м. Київ, Украӥна
}

Емілі Елізабет Дікінсон (1830 - 1886 рр.) написала 1775 віршів. За ії життя було надруковано лише 7 творів, відомі пізніше під номерами $216,318,319,320,86,321,322$. На іiі прохання, вірші були надруковані 
анонімно. Дослідниця Г. Мак Нейл писала: «В роки ії страдництва Емілі Дікінсон висловлювала себе через мовчання - курьозний вислів написане мовчання» [2, с. 6]. Г. Мак Нейл пояснювала це тим, що у поетеси «родина, соціальний статус, стать, регіон - все це знижувало іiі самоствердження, не заважаючи іншим тримати іiі під контролем» [2, с. 33]. Так вона хотіла і так жила у своєму духовно багатому i замкненому світі. I важливим для неї було висловити думки і враження. у поезії й у листах. Останні слова поетеса написала 15 травня 1886p.: «Покликана назад» (Recalled to backward). Вона померла у своїй кімнаті у 56 років тихо і самотньо.

У 50-ті роки $\mathrm{XX}$ ст. відомий літературознавець і текстолог T.Г. Джонсон (Thomas H.Johnson) виконав велику графологічну роботу щодо збереження авторської манери поетеси, також він встановив роки написання творів, дослідивши особливості почерку за його віковими змінами. Повне 3-томне видання творів у 1955 р., і 3-томне видання листів поетеси у 1958p. були опубліковані видавництвом Гарвардського університету.

Примітка: у статті лексика, синтаксис і графіка творів Е.Дікінсон занотовані відповідно до видання «The Complete Poems of Emily Dickinson Ed. by Thomson H. Jonson [without the town of ed. and Publishing House], 2013. 770 p.[3]

Поезія Е. Дікінсон глибоко особистісна. В ній відобразилося усвідомлення власного трагічного буття у світі, свідомо обрана самотність, скептицизм, іронія. Образи реального життя і прекрасної природи у творах поетеси переплітаються з філософськими думками про сенс буття і образами позамежного світу. Гармонія почуттів любові до природи, до краси, до життя розривається з думками про смерть, і світ іiі почуттів, думок і вражень повен контрастів.

Лінгвостилістичний аналіз лексико-семантичних синтагм поетичних творів поетеси надає змогу дослідити унікальність ії світосприйняття i визначити концептуальні образи іiі поетики. Широко вживаним у творах поетеси $\epsilon$ концепт межевого, медіального стану ліричної героїні. Концепт медіального стану висловлюється метафорично - через образи прийнятних і зрозумілих побутових речей, наприклад, образ крихт Memorial crumb - у врші 182, образ моху - Untal the Moss had reached our lips-and covered up- our names - у вірші 449, образ карети 3 Безсмертям - The Carriage held but just Ourselves - And Immortality- у вірші 712, образ мухи - I heard a Fly buzz - when I died --у вірші 465. Змішана реальність концепту медіальності стану складається з реальних побутових речей і речей позамежного світу, які сприймаються як ознаки 
потойбічного світу. Образ медіальності стану ліричної героїні створюється метафорично: відбувається імпліцитне збагачення лексикосемантичнх синтагм новим значенням, прийнятним у поетичному світі. Континуум медіальності стану у творах поетеси розширюється від побутової реальності до створеного в уяві позамежного світу. Медіальний простір умовної дії героїні подано у системі топосів часу ( 486, 574. 686) і місць $(374,465,1603)$.

У вірші 182, 1860 р. образ ліричної героїні зображено на межі двох світів. Зв'язок героїні зі світом живих підтримують червоногруді пташки - Robins - вільшанки - (рос.- малиновки). Сакральність їх образу імпліцитно означається через червоний колір краваток - Red Cravat i поминальних крихт - Memorial crumb. Перехід ліричної героїні до позамежного світу зафіксовано у стані напівсну, можливо, у маренні Being fast asleep. Позамежний світ означено синтагмой Granite lip образ гранітної губи.

Таблиця 1

\begin{tabular}{|c|c|}
\hline $\begin{array}{c}\text { E. Дікінсон. Bipш 182, } 1860 \mathrm{p} \text {. } \\
\text { If I shouldn't be alive } \\
\text { When the Robins come } \\
\text { Give the one in Red Cravat } \\
\text { A Memorial crumb. } \\
\text { If I couldn't thank you }\end{array}$ & $\begin{array}{c}\text { Переклад синтагми. В. Маркова } \\
\text { You will know I'm trying } \\
\text { With my Granite lip! } \\
\text { Знайте-что силюсь вымолвить } \\
\text { Губами гранитной плиты }\end{array}$ \\
\hline $\begin{array}{c}\text { Being fast asleep, } \\
\text { You will know I'm trying } \\
\text { With my Granite lip! }\end{array}$ & $\begin{array}{c}\text { M. Cmpixa: } \\
\text { Знайте-силяться мовити } \\
\text { Губи мої кам'яні }\end{array}$ \\
\hline
\end{tabular}

Смислові синтагми губами гранитной плиты, губи мої кам'яні у поетичному тексті набувають іншого лексичного значення, яке тільки частково збігається із загальноприйнятим. У перекладі В.Маркової вислів губами гранитной плиты сприймається як напис на плиті, епітафія. Але у вірші Е.Дікінсон епітафія є не посланням чи спогадом, відгуком живих про померлу, навпаки - посланням від померлої до живих, тобто образ губы втрачає тут реальне значення i набуває містичного характеру. Granite lip $\epsilon$ контекстуальним семантичним синонімом слова надгробок. Образ Granite lip у перекладі усвідомлюється як річ, що більше належить до нашого світу, це нейтральний вислів, тоді як надгробок є річчю, у нашому сприйнятті, ближчою до іншого, позамежного світу, своєрідними воротами до нього. В оригіналі вислів моєю гранітною губою подано у значенні надгробок. 
Лінгвостилістичний аналіз структури дозволяє розкрити образ ліричної героӥні, що умовно покинула цей світ- If I shouldn't be alive якщо я не буду живою. Він свідчить про неможливість дії ліричної героїні у майбутньому. Вислів If I couldn't thank you означає умовність дії - якщео я не зможу подякувти вам, тому що Being fast asleep - означає евфемізм бувши навіки заснувшей Сполучник If указує на умовну неможливість дії у майбутньому - повернутися назад і подякувати вільшанкам. Лірична героїня Е.Дікінсон поки що перебуває не за воротами іншого світу, а на межі двох світів. Ї̈і межевий, медіальний стан увиразнюється в зіткненні двох елементів структури: Granite $\boldsymbol{i}$ lip i розкриває значення синтагми Memorial crumb - поминальных крошек горсть. Ій відомі таємниці обох світів. Лірична героїня намагається розкрити тайну буття світу, бо вже пройшла його, знає тайну і того, позамежного світу, бо вже побачила його. У перекладі В.Маркової його значення передається одразу, на відміну від оригіналу, де значення закодоване. Однак це аналіз художнього перекладу, де ступінь сенсорності лексичних одиниць $є$ вищим, ніж в оригіналі. У перекладі М. Стріхи образ сакральності крихт не зазначено. Лірична героїня просить насипати Поминальні крихти у Червону Краватку Вільшанкам, коли ті прийдуть (прилетять). Кожен із елементів цієї структури за межами поетичного тексту не виявляє ознак належності до містичного світу, однак у творі вони набувають особливого значення. Прийом онімізації апелятивів Red Cravat, Robins, Granite i Memorial посилює чуттєво-образне, сенсорне сприйняття і самої лексичної структури, і всього тексту. Завдяки їх поєднанню виникають нові образи, яскраві й знакові у поетичному тексті, але неможливі у побутовому мовленні.

Знаменитий вірш Емілі Дікінсон 449 «I died for Beauty» («Я вмерла за Красу») написано у 1862 році, невдовзі після смерті поетеси Елізабет Баррет Браунінг (1861p.) і представляс Е.Дікінсон та їі подругу Е.Баррет Браунінг як друзів і однодумців у поезії. «Лірична героїня вірша 449, можливо, боролася за Красу і загинула, або, можливо, у цьому світі не знайшла Краси і почала шукати іiі в іншому, позамежному світі. Вона знаходиться на межі двох світів у пошуках Краси і зустріла шляхетного однодумця у пошуках Правди, але теж за межами цього світу - When One who died for Truth, was lain In an adjioning Room. Ліричні герої усвідомлюють значення Краси і Правди лише на межі двох світів, бо в цьому світі не знайшли їх». [1. с.36-37] Вірш «I died for Beauty» можна трактувати як пояснення певних біографічних фактів 3 життя Емілі Дікінсон. Американська дослідниця Г. М. Нейл досліджувала підгрунтя створення цього вірша, зв'язок філософських образів Краси, 
Правди й ліричних героїв твору поетеси з аналогічними образами у творах інших авторів.[2, с.160-163] Вірші Е.Дікінсон 449 («I died for Beauty») i 544 («The Martyr Poets - did not tell»), який дослівно перекладається страдники-поети - не розказали (1862 р.) є відгуком на вірш Е. Баррет Браунінг «A Vision of Poets» («Мрія поетів»). Е.Дікінсон вважала, що доля поета-страдника - писати про свій біль мовчки.

«В iї творах відображаються думки про те, що кохання, хвилини щастя - це лише початок розчарувань, втрати, за життям приходить смерть, і найважливіші моменти життя - на межі життя і смерті..Саме тому образ смерті естетизується і подається як образ доброї знайомої, майже подруги».[1, с.48] У вірші 712, ще будучи молодою, вона занотувала одну з найтрагічніших думок, де образ іiі ліричної героїні серед побутових речей ії життя - поруч зі смертю і безсмертям.

Таблиця 2

\begin{tabular}{|c|c|}
\hline Е. Дікінсон. Вiрш 712, 1863p. & Н. Тучинська \\
\hline Весаuse I could not stop a Death - & Я не шукала Смерті, тож \\
He kindly stopped for me - & Вона прийшла по мене, \\
The Carriage held but just Ourselves - & У повіз сіли з нею ми - \\
And Immortality. & Й Безсмертя. Не шалено \\
We slowly drove-He knew no haste & Женемо: поспіху нема... \\
& \\
\hline
\end{tabular}

Образи життя, смерті і безсмертя в поезії Е.Дікінсон стоять нероздільно поруч. У віці 34 роки вона наче передбачила безсмертя своєї поезії й написала у вірші 816: «but when They died, Vitality begun» (помер - $і$ враз життя розпочалось).

Таблиця 3

Е.Дікінсон. Вірш 816, 1864p.

A Death blow is a Life blow to Some Who till they died, did not alive became Who had they lived, had died but when They died, Vitality begun

\section{М.Тарнавська}

Приносить смерть для декого - життя, Для тих, хто жив, не знаючи буття. Хто, якби жив - помер би, але ось Помер - і враз життя розпочалось.

Висновки. У стані глибокої самотності поетеса усвідомлювала неможливість повно розкрити свою душу тим, хто іiі оточував і не розумів. Обраний прийом зображення ліричної героїні у стані медіальності розкриває почуття, потаємні думки й уявлення, естетичні ідеали Е.Дікінсон. Найбільш яскраво образ ліричної героїні у стані медіальності розкрито у віршах 182, 303. 374, 449, 463, 486, 664, 712, 
1100, 1564, 1603, 1632, 1732, 1743, 1769. Образ поетеси Е. Дікінсон, іiі життя і творчість, образ ліричної героїні, духовний зв'язок ії поезії з творчістю інших поетес стали предметом багатьох літературознавчих $\mathrm{i}$ лінгвістичних досліджень.У руслі зазначеної теми в інших статтях ми розглядали духовний зв'язок ліричних героїнь Е.Дікінсон і М.Цветаєвої. Вважаємо, що зазначена тема потребує подальшого докладного i глибокого дослідження.

\section{Література:}

1. Скрипник, Тамара Поэтические контакты времен и континентов: компаративный анализ англоязычной и русской поэзии.. Saarbrucen, Deutschland: Lambert Academic Publishing. 2013. 86 c

2. H.Mc. Neil, Emily Dickinson / 1-st American ed. New York : Panteon Books, 1986. $200 \mathrm{p}$.

3. The Complete Poems of Emily Dickinson. Copyright by Mary L. Hampson / ed. by Thomson. H. Jonson [without the town of ed. and Publishing House], 2013. 770 p. 